\title{
THE ROLE OF CULTURE IN THE ACQUISITION OF FOREIGN LANGUAGES BY MILITARY STUDENTS
}

\author{
Alina Gabriela NEGOESCU, Simona BOŞTINĂ-BRATU, Lucia PALEA \\ “Nicolae Bălcescu” Land Forces Academy, Sibiu, Romania \\ alina.negoescu@yahoo.com, mbostinabratu@yahoo.fr \\ luciapalea@yahoo.com
}

\begin{abstract}
This paper highlights the importance of integrating culture in the teaching of foreign languages to military students. The first section of the paper offers some basic definitions of culture and key terms associated with it. The next part of the paper brings into discussion the relationship between culture and language acquisition. There is an intimate connection between language and culture; not only language is comprised in the definition of culture, but it also reflects culture, thus we cannot separate language teaching from culture. The final part of the paper focuses on the military students as future leaders that need to develop cross-cultural communication skills and be aware of the cultural differences in order to avoid potential failures during communication with soldiers from foreign militaries in theatres of operation or on other international missions that they are assigned.
\end{abstract}

Keywords: culture, language, military students

\section{Introduction}

Today we live in a globalized and multicultural world and the importance of teaching culture in the foreign language classroom is undeniable. Not only culture facilitates communication among people but it also helps people understand themselves in relation to other cultures, thus learning to be intercultural [1]. Educators need to develop intercultural communication skills to their students, especially in the military, in order to be successful in this new era. Consequently, culture has become a vital component of the language acquisition process, in particular in higher education, as it is impossible to teach and learn a language without taking into consideration the cultural context in which it is spoken, the people who speak it and the meaning that they associate with the words and phrases that they use.

\section{Definition of culture}

Defining culture is a highly complex task, as there are numerous definitions of this broad term that includes all aspects of people's life. One of the first and most quoted definitions of culture (in the year 1871, according to Encyclopaedia Britannica [2]) is that of the English anthropologist Edward Burnett Tylor who defines culture, in its ethnographic sense, as a "complex whole which includes knowledge, belief, art, morals, law, custom, and any other capabilities and habits acquired by man as a member of society." Thus culture is closely related to the concept of society. Giddens [3] claims that society is the system of interrelations that binds people, while culture represents the "glue" that connects members of a society due to a common understanding of an accepted way of life.

Tomalin and Stempleski [4] make the 
distinction between the "Big C" and the "little c" elements of culture. The "Big C" refers to history, geography, institutions, art, literature and music and it is called the achievement culture. The "little c" is the behaviour culture and encompasses the daily aspects of life. Peterson [5] includes in the small "c" culture elements such as opinions, gestures, body posture, clothing styles, food, hobbies, popular music, trivia and others. However, teaching culture in a foreign language class should not be reduced to big "C" or little "c" culture. Educators should also consider topics like family, beliefs, scientific and artistic achievements and concentrate on current issues [6].

Tomalin and Hurn [7] argue that culture contains commonly held traditions, values and ways of behaving of people in a certain community. Cultural values include those aspects that people believe are important in life such as family, patriotism, hospitality and fairness, while cultural behaviour covers the knowledge of daily routines and behaviour. On the other hand, another important aspect of understanding culture is the development of cultural sensitivity and cultural skills that enables students to communicate successfully with other cultures. Cultural sensitivity means to be sensible or aware of the cultural differences and similarities among people and understand them without associating a positive or negative value. Thus students need to learn how to be empathetic with other cultures and avoid using or creating stereotypes regarding people in a certain country, of a certain religion or race. Stereotypes limit our communication and interrelation with people from other cultures. Hence, it is vital for students to learn that there is no superior culture.

Therefore, according to Tomalin [8] teaching culture in the language class should not entail only the cultural knowledge that we have comprised in the 'big C', but it should also consider integrating cultural values (things people consider important), cultural behaviour (the little c) and cultural skills (developing intercultural sensitivity through the use of language).

\section{Importance of culture in the foreign language class}

Culture is so important to language acquisition that many scholars argue it is a fifth skill together with listening, speaking, reading and writing. Language and culture are interconnected in a dynamic relation due to the fact that language is comprised in culture and reflects it, and culture is part of language. People communicate and interact with the help of the language and language also supports the development of culture. In its turn, culture shapes language at all levels and structures, take for example the cultural denotations and connotations of words and phrases in semantics (like hot dog, thanksgiving, going Dutch or the associations of colours) or the implicatures in pragmatics. On the other hand, Ozguzel cited in Abushihab [9], emphasizes that "language is a tool for putting culture into practice and for translating it." At the same time language is a cultural product as it cannot survive without a cultural basis.

As we have mentioned before, culture should be an integral part of the language instruction process. As Krasner [10] argued, learners cannot be competent in a language if they are not aware of the cultural context in which the langue is used, they need to learn how to address people, make requests, agree or disagree with someone. Also, learning about a culture helps students to understand how perceptions of the world and of oneself are shaped in relation to others. "The person who learns a language without learning culture risks becoming a fluent fool." [11]

Military students should be able to be flexible, to understand another culture and even function effectively in another society, for instance when they are in a mission, and in order to achieve this goal, only the production of correct grammatical 
utterances or building linguistic competences is not enough. They should learn the cultural conventions, customs and belief, and understand the values of the target language, and to this end culture is an essential element in the language acquisition process.

\section{Teaching culture for military students}

In order to develop intercultural skills, educators should allow students to ask questions and clarify cultural issues, then compare and contrast what they have observed and learned about another culture with their own culture and language and establish common grounds. However, educators should avoid prejudging and stereotyping. Being aware of their culture and processing the new values of the target culture through their existing experiences help students acquire cultural knowledge of the target language and enable a better understanding of their own culture. It is also important to let them observe and reflect on cultural issues from their own perspectives so they would develop personal meanings and become aware and accept the differences between cultures.

In his research, Mehdaoui [12], militates for a thematic-based approach to teaching culture in the foreign language class as opposed to the factual, historical and chronological approach of culture. $\mathrm{He}$ argues that students have a limited understanding of the target culture because of this historical approach of the culture and civilization course, and that educators should focus more on the cultural aspects of the people, such as family, attitudes, religion, education and beliefs. Furthermore, the historical approach is not the only factor responsible for students' shortage of complex cultural knowledge but also due to the emphasis on the proficiency of the language structure and not on culture itself. Moreover students are better motivated when they participate in discussions and discover themselves cultural meanings in class rather than being lectured by teachers.

Although we agree that a thematic-based approach to culture is better than a chronological one, we also plead for an effective combination of approaches depending on the educator and the students' level of proficiency. Thus we can combine the thematic approach to the problemoriented approach, in which students do their part of research with the help and guidance of the language teacher. In this vein, military students are required to prepare oral presentations on topics related to the target culture. By searching and structuring information on certain topics that interest them, they also learn and reflect on the target culture and compare it to their own culture.

Another important issue concerning teaching of culture is to enable students to become involved in genuine cultural experiences using authentic materials such as videos, short films, news, web sites, photographs, newspapers, etc., adapted to students' needs and proficiency level. The video is one of the most effective tools in the language class as it offers students valuable insights both into the language and cultural matters. Educators can concentrate on specific details and create diverse activities based on the video. The video is an engaging tool in the foreign language class, students are usually motivated and interested when it comes to observe and learn from native speakers. It also offers the opportunity to study both the linguistic aspects of language and the non-linguistic, such as gestures and body language that are so important for cultural understanding. For military students and soldiers in general cultural education should be an integral part of their development as leaders. As a matter of fact researchers [13], have described culture as being a weapon for the military. Multinational operations are very common nowadays and being in a different environment is definitely challenging. Sometimes a word, a gesture or a simple behaviour may result in miscommunication, 
misunderstandings or confusion. In order to avoid cultural misunderstandings students as future officers need to acquire cultural sensitivity to help them understand people that are different from themselves, understand their culture and their motivation. Students need to know how to synthesize basic knowledge of the people and their language, their behaviour, way of life and beliefs and teachers can help them succeed. To sum up students need first to be aware of their own culture and then understand other cultures, and finally they need to be flexible and develop empathy towards people of other culture.

One of the biggest inconvenient regarding the teaching of culture in the foreign language class to army cadets is related to the lack of time, fact that there are few classes for discussions in small groups. On the other hand, even if there were more classes it is impossible to teach everything there is to know about a certain culture. Hence, language educators offer only a part of the language and the culture that the language expresses. For this reason, it is important for educators to be aware of this limitation, firstly because they should avoid developing stereotypes and secondly because they should encourage students to learn beyond the foreign language class, and take advantage of the cultural encounters offered to them through the international programs and engage in a constructive way with the diversity in order to develop their knowledge and cultural skills.

\section{Conclusion}

Language and culture are two intertwined elements that cannot be separated without losing the significance of one of them. Therefore, the two should be taught and learned together to achieve the most important goal of the language acquisition process, i.e. the development of intercultural understanding and communication by increasing awareness of students' own culture and the target culture and by building cultural sensitivity and empathy with the target culture. By integrating culture in the language class, language educators provide students with tools for effective communication, helping them to understand and appreciate the values of other cultures and as a result be tolerant with other people and avoid failure in communication.

\section{References}

[1] *** Teaching and Learning Languages: A Guide, Research Centre for Languages and Culture, UniSA, Commonwealth of Australia, 2008, p. 18.

[2] https://www.britannica.com/science/anthropology/The-major-branches-ofanthropology\#ref840179

[3] Giddens, A., Sociology. Cambridge: Polity Press Leadership, 1989, apud Dimmok, C., and Walker, A., Educational Leadership. Culture and Diversity, Sage Publication, London, 2005, p. 8.

[4] Tomalin, B. and Stempleski, S., Cultural Awareness, Oxford: Oxford University Press, 1993, p. 6.

[5] Peterson, B., Cultural intelligence: A guide to working with people from other cultures, Yarmouth, ME: Intercultural Press, 2004.

[6] Mehdaoui, A., A Thematic-Based Approach to the Teaching of British and American Civilisation to Enhance EFL Learners' Intercultural Communication, Journal of Applied Lingustics and Language Learning, I(1), pp. 37-41, 2015.

[7] Tomalin, B. and Hurn, B., Cross-Cultural Communication, London: Palgrave McMillan 2013, p. 196.

[8] Tomalin, B., Culture the fifth language skill, British Council, 2008, retrieved from https://www.teachingenglish.org.uk/article/culture-fifth-language-skill. 
[9] Ozguzel, S., Minorit Language, Culture Teaching and Intercultural Education, Chalkface, 5, pp. 18-20, 1998 apud Abushihab, I., The Effect of Cultural Awareness on Motivating Students to Learn English as a Foreign Language in Jordan, Journal of Foreign Languages Cultures and Civilizations, June 2016, Vol. 4, No. 1, pp. 51-57, 2016.

[10] Krasner, I., The role of culture in language teaching. Dialog on Language Instruction, 13(1-2), pp. 79-88, 1999.

[11] Benett, J., Benett, M., and Allen, W., Developing intercultural competence in the language classroom: Perspectives in second language learning, USA: Information Age Publishing, p. 237, 2003.

[12] Mehdaoui, A., A Thematic-Based Approach to the Teaching of British and American Civilisation to Enhance EFL Learners' Intercultural Communication, Journal of Applied Lingustics and Language Learning, I(1), p. 38, 2015.

[13] Davis, R., Culture as a weapon System, Middle East Report 256, 2010, retrieved from https://blogs.commons.georgetown.edu/rochelledavis/files/CultureAsAWeaponSystem.pdf 